\title{
LINGUISTIC IDEOLOGIES AND THE NATURALIZATION OF POWER IN WARAO DISCOURSE ${ }^{1}$
}

\author{
Charles L. Briggs
}

I want to take up an issue that is succinctly raised by Bourdieu in his Outline of $a$ Theory of Practice. The notion that social groups produce arbitrary modes of thinking and acting, social structures, and the like is common anthropological fare. Interested in the Marxist problematics of power and ideology, Bourdieu (1977: 164) goes on to suggest that "every established order tends to produce (to very different degrees with very different means) the naturalization of its own arbitrariness." A similar concern guides Foucault's work on the emergence in the seventeenth and eighteenth centuries of "a new technology of the exercise of power" that gained its productive capacity through its ability "to gain access to the bodies of individuals, to their acts, attitudes, and modes of everyday behavior" (1980: 124, 125). Gramsci (1971) was interested in the way that hegemony, resistance, and revolution both create and challenge dominant structures; literary critics, such as Williams (1977), and anthropologists, such as Comaroff and Comaroff (1991) and Scott (1985), have drawn on Gramsci's insights in exploring the politics of culture. Taussig has demonstrated the power of commodity fetishism (1980) and terror and shamanism $(1987,1991)$ for naturalizing social relations in post-colonial South America.

My goal in this paper is to link this question to a subject of growing interest in linguistic anthropology - the ideology of language. As Hymes (1974) pointed out years ago, perspectives on language structure and use vary as widely between speech communities as do linguistic structures and speech norms. While linguistics has

${ }^{1}$ ACKNOWLEDGMENTS. My primary debt in this paper is to the residents of the Mariusa region, particularly Santiago Rivera and Manuel Torres, and of the communities of $\mathrm{K}^{\mathrm{w}}$ amuhu and Murako. H. Dieter Heinen and Julio Lavandero greatly assisted me in planning my work in the Delta Amacuro. The Instituto de Investigaciones Científicas in Caracas and the Universidad de Oriente in Cumaná provided intellectual stimulation and institutional support, and the assistance of my colleague Andrés Romero-Figueroa at the latter institution was indispensable. Rosalino Fernández, Librado Moraleda, Santiago Rivero kindly helped me translate the recordings into Spanish. Portions of this paper were presented at the Annual Meeting of the American Anthropological Association in Chicago in a session on Language Ideology, organized by Bambi B. Schieffelin, Paul Kroskrity, and Kathryn Wollard, and in a colloquium in the Department of Anthropology, New York University. Thanks are due Vassar College for a sabbatical leave, a Mellon Grant for Faculty Development, and grants from the Salmon and Travel Funds. The support of the Linguistics Program of the National Science Foundation and the Wenner-Gren Foundation for Anthropological Research, Inc. are also deeply appreciated. 
generally considered speakers' reflections on linguistic structure and use to be uninformative and unreliable, interest in these questions emerged, for example, in Bateson's (1972) discussion of metacommunication. While the contribution of Jakobson's mature writings on the metalingual function (1960), shifters (1957), and metalanguage (1976) is widely recognized, his earliest published paper also focused attention on the role of literature in moving linguistic structures into and out of conscious awareness (1973/1921). Research on the ethnography of speaking has produced much data not only on the many ways that people think about language but the relative importance of language use and linguistic reflexivity as well (contrast Bauman 1983 with Sherzer 1983). Silverstein (1979) has explored the role of linguistic ideologies in shaping scholarly characterizations of language and in attempting to regulate or transform linguistic structures and practices $(1985,1987)$. Much recent research has focused on the relationship between linguistic ideologies and nationalist agendas (Anderson 1991/1983; Gal 1979; Woolard 1985, 1989a, 1989b).

I will suggest that bringing together research on the naturalization of social relations of linguistic ideologies can be extremely productive. The success of this enterprise rests, however, on an adequate conceptualization of the nature of linguistic ideologies, their social distribution, and their location within the processes by which power is produced, naturalized, and challenged. I will argue against viewing ideologies of language simply as part of the linguistic background shared by the members of a speech community. I will suggest that such a perspective is not only empirically unsound and unenlightening but also enters into the process through which scholars naturalize their own interpretive authority. My data are drawn from research conducted with speakers of Warao, an indigenous language of eastern Venezuela, between 1986 and the present. I will begin by discussing the importance of age, gender, and social status in shaping the social distribution of linguistic ideologies. I will then deal in greater detail with a particular example - an exchange of gossip between two male shamans. This case is provided as a means of exploring the situated use of linguistic ideologies in discursive interaction.

\section{Approaches to the comparative study of linguistic ideologies}

If one accepts the value of studying linguistic ideologies, a number of potential theoretical and methodological pitfalls are close at hand. How are we to locate linguistic ideologies? How can they be extracted for scholarly examination? What strategies can we adopt as means of forestalling the emergence of post-colonial dichotomies between "ourselves" versus "Others" or "the West" versus "the rest"? I find an article published ten years ago by the late Michelle Rosaldo (1982) to be quite useful in focusing these issues. Rosaldo draws on extensive fieldwork with the Ilongot of the Philippines in critiquing Searle's (1969) presentation of speech act theory. She draws on Ilongot ideologies of language in showing how Searle "falls victim to folk views that locate social meaning first in private persons-and slight the sense of situational constraint" (1982: 212). She argues that Western linguistic ideologies of 
language are so deeply embedded in Searle's analysis of performative verbs that his work should be read less as presenting universal laws of speech acts than as "an ethnography - however partial - of contemporary views of human personhood and action as these are linked to culturally particular modes of speaking" (1982: 228).

One of the most interesting implications of Rosaldo's comparison of Western and non-Western linguistic ideologies is its potential for discrediting what I call the myth of the linguist as hero. This myth has two facets: first, even such cultural relativists as Boas (1911) and Whorf (1956) believed that linguistic categories "always remain unconscious" for native speakers; anything that the unitiated may say about their own language constitutes a patently false "secondary elaboration." The linguist purportedly is the only individual who can discern patterns of language structure and use without falling victim to the distorting influence of her or his own "native language." Rosaldo's analysis suggests that linguistic ideologies are much too pervasive and subtle to enable students of language the luxury of transcending their own linguistic ethnocentricity. Her work also points to the fruitfulness of treating scholarly studies of language as objects of analysis in the study of linguistic ideologies rather than simply as (ideally) transparent tools for analyzing speech.

While I find the goals of Rosaldo's project to be clearly laudable, I have a number of reservations regarding the way she sets up the comparison. First, like a number of students of linguistic ideology, she presents llongot thinking about language in essentialist terms, positing a single linguistic ideology that would seem to be distributed homogeneously throughout the community. While the opposing, Western view is identified mainly with a particular brand of philosophical discourse, Rosaldo concludes that "certain of our culturally shaped ideas about how human beings act have limited our grasp of speech behavior, leading $u s$ to celebrate the individual who acts without attending to contextual constrains on meaning" (1982: 228; emphasis mine). Exactly how the first person plural is constituted in this assertion is not entirely clear. Reading directly from particular statements regarding language structure and usage to some sort of cognitive common denominator that is evenly and passively inserted into "the brain of each member of a community" (in Saussure's 1959/1916: 19 famous words) seems highly unsound. Interestingly, although Rosaldo argues that Ilongot speech acts must be studied in terms of the way they emerge in social relationships and interactive settings, she treats linguistic ideologies as unconscious residues that provide unproblematic bases for speech and action. While I believe that the cultural roots of linguistic ideologies are profound, I would suggest that they can be best characterized not as cognitive givens but as strategic resources that are deployed in constructing and naturalizing symbolic power. I wish to demonstrate both the empirical and theoretical advantages of the latter approach through an examination of the social and interactional location of linguistic ideologies among speakers of Warao.

\section{The social distribution of Warao ideologies of language}

Where the Orinoco River that traverses Venezuela flows into the Caribbean, it 
explodes into a broad fan of tributaries that create a swampy delta region. Some 20,000 Native Americans, who call themselves Warao, live in this region. I have worked primarily in two dialect areas, the Mariusa region in the central delta and the Murako$\mathrm{K}^{\mathrm{w}}$ amuhu region to the southeast. Formerly, the Warao were hunter and gathers who inhabited the moriche palm groves near the coast. The Mariusa group continues to live primarily in this fashion, while horticulture and fishing are now of more importance in Murako and Kwamuhu.

In turning initially to the ways that men talk about language, one is struck by the amount of time that men spend talking about talk, discussing the nature of discourse and its role in social action. Note that Sherzer (1983) reports that metalinguistics similarly pervades the discourse of Kuna political leaders. I have discussed elsewhere the salience of competing models of language use in monikata nome anaka dispute mediation events and their crucial role in rendering these procedures effective (Briggs 1988). Linguistic ideologies are similarly foregrounded in ahokona serebuyaha, pre-dawn exhortations and demonstrations of ritual knowledge delivered by shamans and political leaders.

In this section I will contrast two types of Warao discursive practices - women's performances of ritual wailing following the death of a relative and men's performances of shamanistic songs. I discuss the fundamentally contrastive character of the ideologies of language that emerge in these two types of discursive practices.

\subsection{Ritual wailing}

Women sit next to the corpse and wail from the time of the death to the point at which they return from the burial grounds. The texted songs composed by each woman consist of refrains, which repeat a kinship term and a formula expressing grief, and textual phrases, longer stretches of discourse that tell of the deceased, his or her life, the victim's relationship to the wailer and other members of the community, and the circumstances that led to the death. Women take turns (based on kinship) sitting next to the body, and the person occupying that location generates a much higher percentage of textual phrases. While most women continue to compose their own textual phrases, the content will be derived in part from the verses sung by the principal wailer.

Two facets of ritual wailing are particularly striking. First, the complex poetic structure of lament texts includes extensive use of reported speech. Stretches of discourse are extracted from discourse events in which women are rarely able to participate actively, such as political rhetoric. Reported speech is used in creating a critical portrait of what is said and done in the community, one that takes male political leaders and shamans to task (cf. Briggs 1992). Second, ritual wailing is highiy polyphonic and intertextual; while all performers embody their own perspective in a distinct text, both textual and musical parameters are coordinated in producing a collective performance (cf. Briggs 1989).

In talking about ritual wailing, women emphasize the importance of the 
collective nature of the performance, noting that emo onakumoni-aweresike onaya 'we couldn't cry apart from one another - we cry very close to one another'. The referent in these expressions is not simply spatial; the women are referring to social relations as indexed by pitch, timbre, and rhythmic coordination. Note that these acoustic features convey powerful affect. ${ }^{2}$ Both men and women assert that only by expressing in ritual wailing the sorrow and rage engendered by the death can the performers and their audiences put the disruptive effects of mourning behind them. My interlocutors attributed the success of this process to a special form of intersubjectivity: onayakore, aobohona eko tia 'when they cry, their thoughts are emptied out'. Obohona can be translated as 'thoughts', 'consciousness', and 'intentionality'. The locus of personal identity, the obohona contains the cognitive and affective elements that are unique to a given individual. When one's obohona is 'emptied out', intentionality and personal agency disappear. The voice that emerges is quintessentially collective, being jointly constructed by a number of performers in concert, and it creates shared understandings of recent events. This voice is accordingly unimpeachable: nome sike onaya; obohonamo onakumoni 'they only cry the truth; they couldn't cry lies'. Even individuals who are being denounced in bold and salacious terms as having caused the death find it difficult to deny the validity of the claims made in laments.

\subsection{Shamanistic song}

I wish to contrast ritual wailing with hoa, songs used by hoarotu shamans in curing and killing (cf. Olsen 1973; Wilbert 1972). Initiates learn to use songs, ritual cigars, the breath, and massage in controlling malevolent spirits. Shamans emphasize two aspects of shamanistic discourse. First, shamans stress the power of the 'names' of hoa spirits that emerge in songs. Hoa songs draw on a specialized lexicon that is unintelligible to non-initiates. This lexicon, when lodged in the poetic, acoustic, and musical patterning of the song, enables the shaman to access the transformative energy that lies behind invisible dimensions of the natural world. Proper use of these 'names' forces the spirits to attend to the shaman's discourse; they also demonstrate the practitioner's knowledge of and power over the distinctive attributes of the spirit in question and its obonona. ${ }^{3}$ A second feature, the linear structure of the song, referred to as anaru 'its path', is central to its performative efficacy. The overall rhetorical structure of the song and the parallelistic patterning evident in clusters of lines and verses enable the practitioner to draw the hoa along a 'path' that either leads from the patient back to the spirit's home or from the hoa's dwelling through the shaman and into a victim's body.

${ }^{2}$ For comparative data on this point, see Urban (1988).

${ }^{3}$ See Sherzer (1982) for a strikingly similar ideology of ritual language that is evident in Kuna society. 


\subsection{Comparison of ideologies connected with ritual wailing and shamanistic song}

In comparing the ideologies associated with ritual wailing and shamanistic song, I would like to stress an initial similarity - both are regarded as highly powerful uses of speech. While hoa songs can either kill or cure, ritual wailing creates structures of feeling that enable communities to overcome the disruptive effects occasioned by death and that significantly affect future events. Beyond this shared feature, however, the two ideologies are diametrically opposed. A first difference is gender - while ritual wailing is cited as a quintessential embodiment of women's social power, shamanistic discourse is the ultimate instantiation of men's social power. The ideological contrasts are also tied to a vast difference in the roles of performer and audience. Ritual wailing is not only by definition collective discourse, but it also exhibits a high degree of recipientdesign, in Sack's (1967) terms. Performers often declare openly who should be listening, how they should interpret what is being sung, and what action should be taken. In hoa, on the other hand, no human audience is present. Shamans sing alone, often out in the forest, when inflicting hoa. Even though the patient and her/his relatives may be listening when the goal is to cure, the discourse is not directed to them. ${ }^{4}$ This exclusion from the overt role of audience is marked by the use of shamans' lexicon.

A key difference in the way that men and women contrast the uses of language associated with the two types of discourse lies in the realm of intentionality. Fascinating recent work by Du Bois (in press), Duranti (1988), and Rosaldo (1982) has pointed to contrasts between speech communities with respect to the role accorded to intentionality. In Warao discourse, the role of intentionality in ritual wailing and hoa songs contrasts as sharply as that cited between the ideologies of language that emerge in Western (scholarly) discourse and the ideologies associated with African divination, Samoan speech-making, and Ilongot discourse (as analyzed respectively by Du Bois, Duranti, and Rosaldo). Hoa songs are characterized as hyper-intentional speech, a means of imposing the shaman's obohona on the obohona of both spirits and victims through the use of 'names' and 'paths'. The social power of wailing is seen as emerging through the displacement of intentionality by 'emptying out' the obohona (rather than using it strategically to control the obohona of others) and by sharing authorship via the process of collective composition.

\section{Strategic uses of linguistic ideologies in gossip}

I would like to forestall three possible readings of the above comparison. First, I do not wish to imply that competing ideologies of language are only evident in speech settings that are highly marked in formal and contextual terms; to the contrary, I will argue in this section that linguistic ideologies can play a crucial role in everyday discourse.

${ }^{4}$ An important exception in this regard pertains to certain sections of curing songs used by wisidatu shamans; here a relative of the patient engages in a dialogue with the malevolent spirits - as embodied in the voice of the shaman (see Briggs 1990). 
Second, much of the data on linguistic ideology that I presented in the previous section emerged in subsequent discussions rather than in the performances themselves, although explicit metapragmatic commentary (cf. Silverstein 1992) does play a larger role in wailing than in shamanistic discourse. Linguistic ideologies can also enter explicitly into the very fabric of the discourse and play a central role in its formal and functional patterning and social/cultural significance. Third, I argued above that ideologies of language are socially distributed. I would argue, however, that the relationship between contrastive ideologies and social differentiation is vastly more complex than a mere correlation would suggest. It is not simply the case that men conceive of language in $X$ terms and women in $Y$ or that shamans assert $Z$ about language. I suggested elsewhere (Briggs 1988) that the juxtaposition of competing models of discourse production and reception is crucial to the success of dispute mediation. In this section I will examine the way that two men deploy contrasting ideologies of language in a conversation that focuses on gossip.

I recorded a dialogue between Manuel Torres and Santiago Rivera ${ }^{5}$ shortly after I took up residence in the Mariusa region in May of 1987. These men, both of whom are about 60 years of age, are two of the three most powerful leaders in the area. Mr. Rivera is the kobenahoro 'governor', the paramount indigenous leader in the region, and he is also one of the most widely feared hoarotu shamans in the delta. Mr. Torres is deemed by many to be the most powerful hoarotu. Both men are skilled in other types of shamanic practice as well. They each have three wives, a clear indicator of their social stature. Mr. Rivera, his wives, several of their children, and I visited Mr. Torres at his house, which lies at the juncture of the Mariusa River and the Caribbean. After exchanging greetings, the two men sat on the floor of the house, face-to-face, less than two feet apart. Lowering their voices and maintaining eye contact with each other, they excluded others from primary roles in the conversation. Their wives and several of their older children and sons-in-law, who were sitting in an adjacent section of the house or lying in nearby hammocks, broke into the conversation from time to time. Since I had turned off a larger tape recorder that was attached to two semi-shotgun microphones shortly before the dialogue began, they forgot that my small cassette tape recorder was still in operation.

Like so much daily talk in Mariusa, the conversations' many twists and turns revolve around accusations against shamans and attempts to cure the victims. Given the status of the interlocutors, many of the charges they discuss had been leveled against them. I will focus on the way that the two men use linguistic ideologies in representing these accusations and - as you might imagine - denying their validity. Early in the conversation, both Mr. Torres and Mr. Rivera admit that they took revenge on shamans from other areas who had killed their relatives by killing them through the use of hoa. These declarations would never have been made in a setting in which they could be held accountable, i.e., if an audience were present, rather than overhearers,

${ }^{5}$ In view of the complex restrictions regarding the use of Warao names, particularly shamans' names, I use pseudonyms in this paper. 
and if anyone who might be listening were not a close relative or ally. In any case, Mr. Rivera contrasts this persona with the way he conducts himself at present in his capacity as 'governor':

(1) (Conversation between Manuel Torres and Santiago Rivera; Mariusa 1987) ${ }^{6}$

$1 \quad$ Atuesike debu asidaha debuya.

'Long ago I really did use bad speech'.

2 Ama ine debu moaya,

'Now I counsel people',

3 maribu nokokitane;

'and they must listen to my words';

$4 \quad$ tatuka uriabane debu moaya.

'I counsel them slowly and carefully'.

Here Mr. Rivera juxtaposes two basic modes of discourse production. The first, debu asida (ha) 'bad speech' is generally used in reference to utterances that reflect anger (yari), jealousy (miahi), or the like. Such discourse does not emerge from careful consideration of one's obonona, the locus of personal identity, cognition, affect, and intentionality. Such uncontrolled speech also fails to respect the obonona of one's interlocutors, and it is likely to generate conflict (see Briggs 1988). When used in the context of talk about shamanism, particularly when the suffix - $h a$ is present, debu asida(ha) is often used to refer to the expression of anger through the use of malevolent shamanism; Mr. Rivera seems to be using the term 'bad speech' both in reference to unreflective speech and shamanistic violence.

In (1) Mr. Rivera contrasts his former use of 'bad speech' with his current reliance on debu moa- 'counseling'. This discourse mode embodies an idealized model of discourse production. Aidamo 'leaders' must 'counsel' the members of their community regarding how one should talk and act. A great deal of 'counseling speech' consists of model utterances that are designed for recontextualization in the mouths of their addressees. 'Leaders' assert that if people speak in this way, social conflict will be avoided.

The conversation between Mr. Torres and Mr. Rivera then turns to recounting the accusations against them. Not surprisingly, the two attempt to refute the charges by labelling them as 'bad speech'. These narratives are characterized as dehe 'gossip'. How do the two men attempt to establish the falsity of these widely circulated narratives? Stories are deemed to be 'gossip' when they do not reflect authoritative knowledge of the events they claim to represent. Determining the 'truth' or 'falsity' of such narratives involves uncovering the many layers of intertextuality that have been built into the narratives, or, as Bauman and I (1990) have referred to it, the process of decontextualization and recontextualization. Mr. Torres and Mr. Rivera thus carefully trace the chain of transmission backwards, as it were, assessing how each narrator

${ }^{6}$ The narrative is broken into lines in accordance with prosodic and grammatical features and in keeping with turn taking. /Slashes that enclose utterances/ in adjacent turns indicate overlaps. 
purportedly told the narrative, how s/he extracted it from previous accounts, and why. The crucial point in the discussion of each narrative was the determination of ahotana 'its beginning'; 'truth' or 'falsity' can be determined when the story has been traced to the purported first telling and the narrators' knowledge of the events in question; motives for narrativizing the events are also examined. Mr. Torres and Mr. Rivera use this process of reconstructing the successive recontextualizations of these narratives as a means of asserting that they are based on a lack of authoritative knowledge as to what took place.

The concepts of 'bad speech' and 'counseling speech' provide an ideological basis for a great deal of talk - and talk about talk - in Warao society. Ahotana 'its beginning' similarly holds the key to the range of linguistic ideologies presented by Warao men in a wide range of speech genres and discussions of performances. Crucially, this concept motivates a generative system for the transformation of dehe nobo 'ancestral narratives', what we would call myths, into shamanic songs. Ahotana also provides a key to grasping the complex system of epistemic evaluatives in Warao suffixes and particles that grammatically encode assertions regarding the nature and certainty of the evidence on which one's utterance rests. It would similarly be possible to connect these facets of linguistic ideologies with Warao ideologies of emotion, the person, the body, and so forth (see Briggs 1988, 1992). Indeed, I believe that the concepts that I have outlined are quite telling with respect to the way Warao conceive of and use language.

I believe, however, that it would be misleading to simply assert that the concepts of 'counseling', 'bad speech', and 'the beginning' provide keys to understanding the linguistic ideologies that underlie Warao men's speech. Let us return to the conversation between Mr. Rivera and Mr. Torres. Recall their status as two of the most powerful leaders in the Mariusa region and perhaps the most feared shamans in the delta. Directly confronting such individuals would be viewed as suicide. As their conversation itself bears witness, however, people spend a great deal of time criticizing what are seen as their abuses of power - once they are safely out of earshot. While the two men often adopt a mocking, parodic tone when recounting this gossip and an air of bravado in reporting their own responses, hushed, serious, and genuinely fearful reactions to particularly poignant charges also emerge. Indeed, such 'gossip' provides a powerful - if precarious - means of constraining their actions. If community opinion, as partially generated and ratified through such narratives, were to generate a consensus in opposing the two, particularly if it were to be transformed into public discourse by women's wailing (see Briggs 1992), it could lead to loss of their political power, expulsion from the area, denunciation to governmental authorities, or retaliation.

The two men accordingly spend a great deal of time attempting to discredit a series of charges levelled against them by a man named Francisco Gómez (who is not a shaman), Basilio López (a specialist of lesser stature who practices a different sort of shamanism), and a number of female narrators. Mr. Rivera and Mr. Torres dismiss the narratives told by the women (as repeated by the two men's wives and daughters). They claim that naminaharone, are dehe waraya, dehe waraya, dehe waraya 'even though 
they don't know what they're talking about, they're always telling gossip and telling gossip and telling gossip'. What basis do they have for asserting that these individuals are ignorant of the events in question? People very seldom see shamans attempting to inflict hoa or other types of supernatural violence. The most reliable evidence is rather provided by the dreams that come to shamans after treating the patient. Access to the ahotana or 'beginning' of these witchcraft accusations is thus predicated on forms of symbolic capital, to use Bourdieu's term, that women are very seldom able to accumulate. The concept of ahotana marginalizes women's narratives - and thus their attempts to call the authority of men like Mr. Rivera and Mr. Torres into question by fiat. The two men have a great deal of fun tracing the 'gossip' back to accounts by Mr. Gómez and Mr. López that they saw the two shamans in their dreams. This is particularly laughable in the case of Mr. Gómez; since he possesses no shamanic capital himself, he could not possibly have 'seen' a hoarotu in his dreams. ${ }^{7}$ While Mr. López is a shaman, he is a bahanarotu, not a hoarotu, and it is accordingly impossible for him to have 'seen' a hoarotu in his dreams. The manner in which Mr. Rivera claims to have dismissed Mr. López's account in a conversation with his accuser is particularly telling:

(2) (Continuation of conversation; SR = Santiago Rivera, MT = Manuel Torres)

1 MT Warao are era.

'People tell a lot of gossip'.

2 SR Warao arebu.

'People gossip'.

3 MT Warao, warao arebu.

'People, people gossip'.

4 SR "Ama ihi obohonamo, obohonamo, lobohonamo, obohonamol - tida monuka!"

"'So you're a liar, a liar, /a liar, a liar/ - you're just like a woman!"'

$5 \quad$ MT

/"obohonamo, obohonamo"/

/"'a liar, a liar"'/

6 SR "¿Qué pasa, pues?"

"'So what's the matter with you?"'

7 "Ihi noboto?"

"'Are you a child?"'

8

"Ihi idamo diana, /ihi kate kayamo idamo diana."/

"'You're an old man already, /and you aren't even as old as we are!"'/

$9 \quad$ MT

/"ihi kate idamo mi diana!"/

/"'look, you're old too!"'/

10 SR Tanaha mi diana ine.

${ }^{7}$ Francisco is skilled in treating lacerations, venomous stings, and the like; this type of curative practice does not, however, involve shamanic dreams or contact with powerful malevolent spirits, such as hoa. 
'That's what I said to him'.

Lacking the symbolic capital that accrues to a powerful hoarotu shaman, Mr. López is reduced to the status of those members of society who are most impotent, in the terms advanced by Mr. Rivera and Mr. Torres.

The implications of the situated use of these linguistic ideologies is not confined to this conversation or these particular events. I wish to claim that such strategic uses of linguistic ideologies play an important role in naturalizing social inequality and social power in Warao society. Performances of such discourse forms as ritual wailing and 'gossip' narratives, along with shamanic songs, ancestral narratives, and political rhetoric, constitute powerful forms of social action. I argue elsewhere that women's ritual wailing provides a crucial means of appropriating and criticizing types of authoritative male discourse to which women are seldom granted access as performers (Briggs 1992). 'Gossip' plays an important role in Warao social life by virtue not only of its potential uses in generating collective criticism of 'leaders' but also in that it is accessible, mutatis mutandis, to everyone. It thus provides entre into negotiations regarding questions of power and violence for women and for men who are not political leaders or shamans. Mr. Rivera and Mr. Torres are not only two of the most powerful 'leaders' in the region, but they enter into social conflict frequently, using shamanic violence to achieve their ends. When either man seems to have flagrantly abused his power, 'gossip' provides a means of attempting to achieve the consensus needed to force public disclosure of his actions in a dispute mediation ceremony. ${ }^{8}$

Recounting this 'gossip' and attempting to discover its ahotana is thus an important form of collaboration between the two allies. If either man should be forced to defend himself in dispute mediation, it would be extremely useful to have worked out a good defense in advance. This tactic is particularly valuable in that his friend would be likely to serve in the role of either key witness or officiating 'leader', thereby creating an excellent opportunity to recontextualize these rhetorical strategies. Note that the two men devote much of the conversation to asserting what they would say in response to the charges advanced through 'gossip' if an open confrontation should take place. Part of the social power of what they are saying lies not in its utterance in the present interaction itself but in its potential recontextualization. The entextualization process, the shaping of discourse into textual segments that can be lifted out of the conversation for future use (see Bauman and Briggs 1990), is not simply oriented toward dispute mediation events. The two men are clearly aware that their families are listening and, at times, collaborating in revealing the 'gossip' that is being told about them. As they trace the ahotana of the 'gossip', Mr. Rivera and Mr. Torres issue a number of warnings that are designed to be relayed to the individuals who are spreading the 'gossip'. They assert that they will use their power as 'leaders' in assessing a cash fine against the women for concocting baseless 'gossip'. The warnings for the two men who

${ }^{8}$ See Abrahams (1983), Besnier (1989), Brenneis (1984), Goodwin (1980, 1990) and Haviland 1977) for comparative data on the interpersonal dynamics and socio-political effects of information lisclosure and withholding in gossip. 
claim to have seen Mr. Rivera and Mr. Torres in their dreams are more pointed. They threaten to send hoa against them: if they are really hoarotu shamans - as their claims to having 'seen' hoarotu shamans in their dreams would suggest - they can simply deflect the invading spirits; if not, they may die.

I thus suggested that Mr. Rivera and Mr. Torres muster linguistic ideologies in developing strategies for discrediting the 'gossip' directed against them by individuals who lack the same degree of social and supernatural power. Their account claims to reveal the 'truth', asserting that their detractors are only telling 'lies'. As Foucault (1980: 131) argues, presenting truth claims goes much deeper than simply validating a particular body of facts:

Each society has its régime of truth, its 'general politics' of truth: that is, the types of discourse which it accepts and makes function as true; the mechanisms and instances which enable one to distinguish true and false statements, the means by which each is sanctioned; the techniques and procedures accorded value in the acquisition of truth; the status of those who are charged with saying what counts as true.

Mr. Rivera and Mr. Torres use linguistic ideologies in attempting to exercise tighter control over the economy of truth and, consequentially, in denying their adversaries access to the socially significant discourses that are regulated by this economy. These ideologies naturalize a social hierarchy of discursive forms; if women and nonspecialist men lack direct access to the ahotana, then their discourse is mere 'gossip' which lacks the power that resides in shamanic speech, accounts of dreams, ancestral narratives, and political discourse. Such uses of linguistic ideologies naturalize the dominance of elder men who possess substantial political and shamanic capital. Only individuals with access to the 'beginning' of recent events and of shamanic power - which also lies in the dreaming of initiated men - can speak authoritatively and expect their words to become the basis for collective action. Linguistic ideologies thus provide crucial means of attempting to naturalize the social structural status quo.

\section{Implications for the study of "ideologies of language"}

Few linguistic anthropologists still hold to a Saussurean perspective on the autonomy of language or with his notion that "language exists in the form of a sum of impressions deposited in the brain of each member of a community, almost like a dictionary of which identical copies have been distributed to each individual" (Saussure 1959/1916): 19). Many practitioners have come to embrace a heteroglossic view that characterizes language-from phonological features to lexical items to stylistic and generic alternatives to multilingualism - as highly contested ground. This same perspective is now displacing statements regarding the ideology of language held by a particular social group in favor of recognizing that, like other cultural tenets, beliefs about language are multiple, competing, contradictory, and contested. I have argued that it is necessary to systematically examine the full range of ideologies of language evident within particular communities and to pay close attention to their social distribution.

The data I presented here suggest that ideologies of language are not productively 
viewed as fixed types, nor can their relationship with social factors be adequately explained in correlational terms. It is not simply the case that Warao women think about language in one way, men in another, or that one type of ideology prevails in a given sort of event and a contrastive variety in another. Clearly, mature men particularly shamans - are much more invested in asserting the centrality of 'counseling speech' and the ahotana of discourse. It should be pointed out, however, that $\mathrm{Mr}$. Rivera's and Mr. Torres' wives, sons, and sons-in-law collaborate in denouncing the baselessness of the 'gossip' that was circulating about the two shamans. Linguistic ideologies do not simply constitute underlying frameworks that implicitly shape the discourse of particular individuals or social groups. I have rather argued that linguistic ideologies are crucial resources for according social power to strategies for the production and reception of discourse. My analysis of the conversation between $\mathrm{Mr}$. Rivera and Mr. Torres further suggests that linguistic ideologies provide key tools for naturalizing unequal access to particular discourses as well as control over their production and reception. This is not to say that such uses of dominant - and dominating - linguistic ideologies are always successful. The crucial role of ideologies of language in this process renders them excellent loci for challenging dominant discourses, institutions, and individuals. Women's ritual wailing gains social power precisely because it appropriates men's discourse and challenges male views of how it is produced and received (see Briggs 1989, 1992). Such heteroglossic moves thus provide insight into the possibilities for calling social power into question by exposing the means by which it is naturalized discursively.

I would like to suggest that adopting the sort of perspective on linguistic ideologies that I have outlined can help link research on the micro- and macro-sociology of language, that is, between particular speech forms and interactions on the one hand and ideologies of language and language practices as they emerge at the level of the nation-state on the other (see for example Adams and Brink 1990; Gal 1979; Silverstein 1987; Woolard 1985, 1989a, 1989b). Exploring the strategic use of these ideologies brings up questions of access to linguistic resources - and thus larger questions of power and political economy - at all levels of analytic inclusiveness, from events to social groups to communities to nation-states.

Having made a case for the value of "linguistic ideology," I would like to conclude by questioning first the adjectival and then the nominative components of the term itself. I have suggested that Warao spend a great deal of time talking about speech and that such talk is socially quite consequential. It would be highly inaccurate, however, to suggest that such "linguistic ideologies" refer exclusively to dimensions of linguistic structure and use. These ideologies focus just as squarely on social relations, particularly social inequality, concepts of the person, epistemological categories, and the like. It may thus be misleading to speak in a comparative vein of either "linguistic ideologies" or "ideologies of language" in view of the fact that these ideologies will often encompass cultural foci that appear quite extraneous. If analysts simply pull out those elements that conform to their definitions of language and linguistics, the character of these ideologies - and particularly their functional relations with the discourse practices in which they emerge - will be displaced by an empirically and theoretically impoverished 
caricature that offers the advantage of ready incorporation into existing analytic frameworks. We have certainly become sufficiently sophisticated to know that we cannot look for direct counterparts to analytic concepts in situated discourse practices, whether in Western or non-Western societies. I fear that referring to ideologies that regulate and empower discursive strategies as "linguistic ideologies" may excuse researchers from exploring dimensions that extend beyond even a broad definition of the term "linguistic."

Problems with the concept of "ideology" have been often discussed. "Ideology" tends to conjure up the notion of a rather fixed, abstracted, and circumscribed set of beliefs. It also seems to imply some distance from social action and particularly from the constitution of ideologies in action. If "linguistic ideologies" are accordingly relegated to either a bounded "conceptual" domain or are cast as an additional level of linguistic patterning, researchers will encounter more difficulty in connecting work in this area with questions of history, social relations, and power. Moreover, "ideology" presupposes an opposing (if often implicit) category that is granted primacy as being "true" or "real." This formulation thus casts linguistic ideologies in a secondary role with respect to either the "objective structures" of political economy (as Bourdieu 1977 would have it) or the linguist's scientific understanding of how language "really" works. For these reasons, we might be well advised to follow Foucault in adopting the term "strategies" in lieu of "ideologies."19

Treating linguistic ideologies as epistemologically subordinate or as mere false consciousness would have two unfortunate effects on research in this area. First, it tends to marginalize the study of linguistic ideologies by casting them as erroneous and derivative notions that can only provide insight into the means by which Others celebrate their own mystification. I have rather argued that these metadiscursive strategies constitute central and productive facets of both discourse and social life. Second, the term seems to carry the implication that the "ideologies" of Others, be they "mainstream" politicians in first world countries or marginalized members of postcolonial societies, must be exposed through the operation of a scientifically-grounded understanding of what "really" happens; this formulation may tell us more about the efforts of academics to legitimate their own discourse rather than to illuminate the complex dialogic relation between what I would like to call metadiscursive strategies, scholarly and otherwise. Note that Mr. Rivera's and Mr. Torres' conversation centers on representing the words of others and presenting an analysis of the metadiscursive strategies that underlie them. I argued that such a move is less an objective presentation of the "facts" of the matter than an attempt to naturalize the great -

9 Another alternative wouuld be to use Bourdieu's (1977) concepts of the "habitus" and "practice." Relegating ideologies to the habitus would, however, seem to reintroduce many of the same difficulties. The notion that essentially the same habitus is inculcated into the members of a common social group seems problematic, as is Bourdieu's dismissal of conscious reflexivity as offering possibilities for gaining insight into and challenging symbolic power. While "practice" offers advantages in being more closely associated with social action and strategic innovation, Bourdieu similarly denies the possibility of gaining conscious insight into practice. 
although not complete - control that older men exercise over the means by which discourse is accorded symbolic power. We must be wary of simply undertaking the same process as we, in turn, develop metadiscursive strategies for representing and analyzing the discourse of others in scholarly texts. I thus propose a shift from linguistic ideologies to metadiscursive strategies not simply as a means of achieving greater empirical adequacy but also of asserting that scholarly discourse is no less strategic and ideological than "ideologies of language."

\section{References}

Abrahams, Roger D. (1983) The man-of-words in the West Indies: Performance and the emergence of creole culture. Baltimore: Johns Hopkins University Press.

Adams, Karen L., and Daniel Brink (ed.) (1990) Perspectives on official English: The campaign for English as the official language of the USA. Berlin: Mouton.

Anderson, Benedict (1991/1983) Imagined communities: Reflections on the origin and spread of nationalism. London: Verso.

Bateson, Gregory (1972) Steps to an ecology of mind. New York: Ballantine Books.

Bauman, Richard (1983) Let your words be few: Symbolism of speaking and silence among seventeenthcentury Quakers. Cambridge: Cambridge University Press.

Bauman, Richard and Charles L. Briggs (1990) "Poetics and performance as critical perspectives on language and social life." Annual Review of Anthropology 19: 59-88.

Besnier, Niko (1989) "Information withholding as a manipulative and collusive strategy in Nukulaelae gossip." Language in Society 18: 315-41.

Boas, Franz (1911) "Introduction." In Franz Boas (ed.), Handbook of American Indian languages. Washington: Government Printing Office.

Bourdieu, Pierre (1977) Outline of a theory of practice. Richard Nice (transl.) Cambridge: Cambridge University Press.

Bourdieu, Pierre (1982) "The economics of linguistic exchanges." Social Science Information 16: 645-68.

Bourdieu, Pierre (1991) Language and symbolic power. Gino Raymond and Matthew Adamson (transl.) Cambridge, MA: Harvard University Press.

Brenneis, Donald L. (1988) "Telling troubles: Narrative, conflict and experience." Anthropological Linguistics 30: 279-91.

Briggs, Charles L. (1988) "Disorderly dialogues in ritual impositions of order: The role of metapragmatics in Warao dispute mediation." Anthropological Linguistics 30: 448-91. 
Briggs, Charles L. (1989) 'Please pass the poison': The poetics of dialogicality in Warao ritual wailing. Conference on lament, Austin, Texas.

Briggs, Charles L. (1990) "The effectiveness of dialogue - a return visit to Lévi-Strauss' analysis of a Kuna shamanistic song by way of the Delta Amacuro of Venezuela." Paper presented at the Annual Meeting of the American Anthropological Association, Chicago.

Briggs, Charles L. (1992) "'Since I am a woman, I will chastise my relatives': Gender, reported speech, and the (re)production of social relations in Warao ritual wailing." American Ethnologist 19: 337-61.

Comaroff, Jean and John Comaroff (1991) Of revelation and revolution: Christianity, colonialism, and consciousness in South Africa. Chicago: University of Chicago Press.

Du Bois, John W. (in press) "Meaning without intention: Lessons from divination." In Jane H. Hill and Judith T. Irvine (eds.), Responsibility and evidence in oral discourse. Cambridge: Cambridge University Press.

Duranti, Allesandro (1988) "Intentions, language, and social action in a Samoan context." Journal of Pragmatics 12: 13-33.

Foucault, Michel (1980) Power/knowledge: Selected interview and other writings, 1972-1977. Colin Gordon, et. al (transl.) New York: Pantheon.

Gal, Susan (1979) Language shift: Social determinants of linguistic change in bilingual Austria. New York: Academic Press.

Goffman, Erving (1981) Forms of talk. Philadelphia: University of Pennsylvania Press.

Goodwin, Marjorie Harness (1980) "He-said-she-said: Formal cultural procedures for the construction of a gossip dispute." American Ethnologist 7: 674-95.

Goodwin, Marjorie Harness (1990) He-said-she-said: Talk as social organization among Black children. Bloomington: Indiana University Press.

Gramsci, Antonio (1971) Selections from the prison notebooks of Antonio Grarisci. Quintin Hoare and Geoffrey Nowell Smith (transl.) New York: International Publishers.

Hanks, William (1987) "Discourse genres in a theory of practice." American Ethnologist 14: 668-92.

Haviland, John Beard (1977) Gossip, reputation, and knowledge in Zinacantan. Chicago: University of Chicago Press.

Hymes, Dell (1974) Foundations of sociolinguistics: An ethnographic approach. Philadelphia: University of Pennsylvania Press.

Jakobson, Roman (1957) Shifters, verbal categories, and the Russian verb. Cambridge, Mass.: Harvard University Russian Language Project.

Jakobson, Roman (1960) "Closing statement: Linguistics and poetics." In Thomas A. Sebeok (ed.), Style in language. Cambridge, Mass.: M.I.T. Press, p.350-77. 
Jakobson, Roman (1973/1921) "Modern Russian poetry: Velimir Khlebnikov." In Edward Brown (ed.), Major Soviet writers. London: Oxford University Press, p.58-82.

Jakobson, Roman (1976) "Metalanguage as a linguistic problem." In Stephen Rudy (ed.), Roman Jakobson: Selected writings, vol. 7, Contributions to comparative mythology: Studies in linguistics and philology, 1972-1982. Berlin: Mouton, p.113-21.

Olsen, Dale (1973) "Music and shamanism of the Winikina-Warao Indians: Songs for curing and other theurgy." Unpublished Ph.D. dissertation, University of California, Los Angeles.

Rosaldo, Michelle Z. (1982) "The things we do with words: llongot speech acts and speech act theory in philosophy." Language in Society 11: 203-35.

Sacks, Harvey (1967) Unpublished lecture notes. University of California, Irvine.

Saussure, Ferdinand de (1959/1916) A course in general linguistics. Wade Baskin (trans.) New York: McGraw-Hill Book Company.

Scott, James C. (1985) Weapons of the weak: Everyday forms of peasant resistance. New Haven, CT: Yale University Press.

Searle, John R. (1969) Speech acts: An essay in the philosophy of language. Cambridge: Cambridge University Press.

Sherzer, Joel (1982) "The interplay of structure and function in Kuna narrative, or: How to grab a snake in the Darien." In Deborah Tannen (ed.), Analyzing discourse: Text and talk. Washington: Georgetown University Press, p.306-22.

Sherzer, Joel (1983) Kuna ways of speaking: An ethnographic perspective. Austin: University of Texas Press.

Silverstein, Michael (1979) "Language structure and linguistic ideology." In Paul R. Clyne, William Hanks, and Carol L. Hofbauer (eds.), The elements: A Parasession on linguistc units and levels. Chicago: Chicago Linguistic Society, p.193-247.

Silverstein, Michael (1981) The limits of awareness. Austin, Texas: Southwest Educational Development Laboratory.

Silverstein, Michael (1985) "Langauge and the culture of gender: At the intersection of structure, usage, and ideology." In Elizabeth Mertz and Richard J. Parmentier (eds.), Semiotic mediation: Sociocultural and psychological perspectives. Orlando, Fl.: Academic Press, p.219-59.

Silverstein, Michael (1987) "The monoglot "standard" in America." Working Papers and Proceedings of the Center for Psychosocial Studies 13: 1-24.

Silverstein, Michael (1992) "Metapragmatic discourse and metapragmatic function." In John A. Lucy (ed.), Reflexive language: Reported speech and metapragmatics. Cambridge: Cambridge University Press (forthcoming).

Taussig, Michael (1980) The devil and commodity fetishism in South America. Chapel Hill: University of North Carolina Press. 
Taussig, Michael (1987) Shamanism, colonialism, and the wild man: $A$ study in terror and healing. Chicago: University of Chicago Press.

Taussig, Michael (1991) The nervous system. New York: Routledge.

Urban, Greg. (1988) "Ritual wailing in Amerindian Brazil." American Anthropologist 90: 385-400.

Whorf, Benjamin Lee (1956) Language, thought, and reality: Selected writings of Benjamin Lee Whorf. John B. Carroll (ed.) Cambridge, MA: M.I.T. Press.

Wilbert, Johannes (1972) "Tobacco and shamanistic ecstasy among the Warao of Venezuela." In Peter Furst (ed.), Flesh of the gods: The ritual use of hallucinogens. New York: Praeger, p.55-83.

Williams, Raymond (1977) Marxism and literature. London: Oxford University Press.

Woolard, Kathryn A. (1985) "Language variation and cultural hegemony: Toward an integration of sociolinguistic and social theory." American Ethnologist 12: 738-48.

Woolard, Kathryn A. (1989a) Double talk: Bilingualism and the politics of ethnicity in Catalonia. Stanford: Stanford University Press.

Woolard, Kathryn A. (1989b) "Sentences in the language prison: The rhetorical structuring of an American language policy debate." American Ethnologist 16: 268-78. 